\title{
Fertilization Rate and Irrigation Scheduling in the Nursery Influence Growth, Insect Performance, and Stress Tolerance of 'Sutyzam' Crabapple in the Landscape
}

\author{
John E. Lloyd ${ }^{1}$ \\ Department of Plant, Soil and Entomological Sciences, University of Idaho, \\ Moscow, ID 83844-2339

\section{Daniel A. Herms Department of Entomology, The Ohio State University, Ohio Agricultural Research and Development Center, 1680 Madison Avenue, Wooster, OH 44691}

\author{
Mary Ann Rose \\ Department of Horticulture and Crop Science, The Ohio State University, \\ Columbus, OH 43210
}

Jennifer Van Wagoner

Department of Plant, Soil and Entomological Sciences, University of Idaho, Moscow, ID 83844-2339

Additional index words. Malus, host plant resistance, secondary metabolism, resource allocation, phenotypic plasticity, gas exchange, water relations

\begin{abstract}
The objective of this study was to determine if fertilization and irrigation practices in the nursery affect plant growth and stress resistance following outplanting in the landscape. Flowering crabapple (Malus) 'Sutyzam', grown in containers under factorial combinations of two irrigations schedules (containers irrigated at $25 \%$ or $50 \%$ container capacity) and three rates of fertilization $\left(\mathrm{N}\right.$ at $\left.50,200,350 \mathrm{mg} \cdot \mathrm{L}^{-1}\right)$ in a nursery in 1997 were outplanted in a low maintenance landscape in 1998. Trees from the high fertility regime grew faster in the landscape the year of transplant. Tree growth in the landscape was positively correlated with $\mathbf{N}$ concentration in plants in the nursery and negatively correlated with concentrations of phenolics in the foliage in the landscape. However, the trees showing the greatest amount of diameter growth had the lowest concentrations of foliar phenolics. Trees with low concentrations of phenolics also exhibited a greater potential for herbivory by larvae of the eastern tent caterpillar, gypsy moth, and whitemarked tussock moth. Additionally, trees exhibiting rapid growth in the landscape also had reduced photosynthesis during summer drought compared to slower growing trees, suggesting a reduced drought tolerance in the landscape. Differences in growth and stress resistance did not carry beyond the year of transplant. Our results illustrate that irrigation and fertilization methods in the nursery can influence growth post transplant, however fertilization also appears to have a significant impact on stress resistance traits of the trees. These impacts from the nursery production methods had no effect after plants had acclimated to the conditions in the landscape during the year following transplant.
\end{abstract}

Nutrient management in nursery production of containerized plants can optimize rapid growth, which is necessary to shorten production schedules and maintain profit margins as well as affect establishment success after

Received for publication 1 June 2005. Accepted for publication 22 Dec. 2005. We thank Drs. Robert Tripepi, and Mark Schwarzlaender and the several anonymous reviewers for their critical reviews of this manuscript. Nitrogen and phenolic analyses were conducted by William J. Mattson, USDA Forest Service, Rhinelander, WI. Salaries and research support were provided by State and Federal funds appropriated to the Ohio Agricultural Research and Development Center, The Ohio State University. ${ }^{1}$ To whom reprint requests should be addressed; e-mail jlloyd@uidaho.edu. transplant into a landscape environment. 'Nutrient loading' of plants in the nursery has been proposed as a strategy for increasing growth of transplants the years following outplanting, when nutrient uptake may be limited by root damage. Remobilization of stored nutrients stimulates increased shoot growth after transplanting (McAlister and Timmer 1998). However, nurseries are also under increasing pressure to conserve water and limit nutrient runoff. These conflicting management objectives may be resolved when water and nutrient requirements for optimal growth have been determined. Recent studies have shown that it is possible to decrease fertilizer use in nursery production of containerized plants without sacrificing plant growth (Cabrera, 2002; Rose et al., 1999; Struve and Rose, 1998). In fact, research suggests that reducing irrigation in the nursery actually increases root development and post-transplant success of some ornamental plants (Franco et al., 2002 a,b; Khan et al., 1996).

Hamilton et al. (1981) has suggested that conservative use of fertilizer in nursery production may increase establishment and stress tolerance of plants once they reach the landscape. They argue that lower nutrient concentrations increase root growth relative to shoot growth, resulting in increased stress tolerance. Other studies have shown that reduced fertility regimes can increase insect and disease resistance by decreasing the nutritional value of the plants for microbes and insects, and by increasing concentrations of plant defense compounds (Herms, 1999; Herms and Mattson, 1992; Rieske et al., 2003).

While reducing fertilization and irrigation frequency in the nursery may be an opportunity to enhance plant establishment post transplant in the landscape, little research has addressed the wide spectrum of influences that limitations may have beyond above and below ground growth. The objectives of our study were to determine what impacts fertilization and irrigation practices in the nursery have on growth and innate stress resistance traits of a woody plant following outplanting into the landscape.

\section{Material and Methods}

Rooted cuttings of Malus 'Sutyzam' were transplanted to $8.6 \mathrm{~L}$ (no. 3) polyethylene containers with soilless growing media (Metro Mix 510; The Scotts Co., Marysville, Ohio). Trees were placed in an outdoor container yard (in Columbus, Ohio) and hand watered. After an establishment period of about 11 weeks, the experiment was set up in a randomized complete block design (eight blocks) with stem diameter used as a blocking factor. Fertilizer and irrigation treatments began on 1 July 1997 and continued through 8 Oct. 1997 and 12 Nov. 1997 respectively. During the treatment period plants were covered to exclude rainfall. Treatments consisted of factorial combinations of three fertilizer and two irrigation treatments provided through an electronic fertigator that calculated the amount of water and fertilizer needed to obtain the rates listed below (Rose et al., 1998). Fertilizer concentrations (FC) were nitrogen at 50,200 , and $350 \mathrm{mg} \cdot \mathrm{L}^{-1}$ from soluble $24 \mathrm{~N}-3.5 \mathrm{P}-13.3 \mathrm{~K}$ fertilizer (Peters 24-8-16, Scotts Co., Marysville, Ohio). A system of water-driven proportional injectors (Dosatron International, Inc., Clearwater, Fla), polyethylene tubing, and $4 \mathrm{~L} \cdot \mathrm{h}^{-1}$ emitters delivered fertilizer solutions to the pots until 8 Oct. 1997 when fertilization was discontinued.

Irrigation treatments were scheduled based on moisture tension levels within the medium. The high moisture treatments were irrigated at $7 \mathrm{kPa}$, which corresponded to $50 \%$ container capacity moisture deficit; low moisture treatments were irrigated at $18 \mathrm{kPa}$, which corresponded to $25 \%$ container capacity moisture deficit. Container capacity was determined 
in two separate trials to be about $4 \mathrm{~L}$ for the 8.6-L container with the soilless media. Each irrigation event restored container capacity; low moisture treatments received $2 \mathrm{~L}$ and high moisture treatments received $1 \mathrm{~L}$ during each event. Irrigation events were monitored and controlled by electronic tensiometers (Rose 1994). A single tensiometer was used to control each moisture setpoint, with ceramic cups positioned $5 \mathrm{~cm}$ from the bottom of the pot, equidistant from the side of the pot and the stem axis. Tensiometers controlled irrigation through 12 Nov. 1997 when irrigation ceased. The following spring, trees were hand watered as needed with no additional fertilization.

On 26 June 1997, a preliminary harvest of three representative plants was made to assess initial dry weight and nutrient status before treatments began. On 9 Sept. 1997, while plants were in active growth, 1 plant per block and treatment combination was harvested ( 8 plants per treatment combination for a total of 48 plants). On 1 Dec. 1997, after leaf abscission, another 1 plant was harvested from each block and treatment combination. Leaves that abscised from trees harvested in December were collected in mesh bags placed over the trees in late October. On each harvest date, trees were separated into leaves, stems, and roots. Leaf areas were measured in September only using a LI-COR 3100 area meter. All samples were dried at $70^{\circ} \mathrm{C}$, weighed, and ground to pass through a 40-mesh screen. Samples were sent to the Ohio State University Research ExtensionAnalytical Laboratory, Wooster, Ohio for dry combustion analysis of nitrogen (Rose, unpublished).

Malus 'Sutyzam' trees from the container research nursery, were planted in the same randomized complete block design at the Ohio Agricultural Research and Development Center (OARDC) in Wooster, Ohio on 29 May 1998. The trees were divided into eight blocks with six trees per block representing the treatments they had been under in the nursery for a total of 48 trees.

The site had formerly been planted with turf, which was removed around each planted tree. Surrounding vegetation was mowed during the experiment. A low maintenance landscape was maintained in the field through 1998 and 1999. Trees were not fertilized or mulched and were irrigated only three times: on the day of transplanting, again one week later, and finally on 4 Aug. 1998, during a period of drought.

To determine effects of prior year nursery treatment on tree physiology we measured caliper growth, height growth, photosynthesis, stomatal conductance, and phenolic concentration of foliage. Caliper growth, measured as the increase in trunk diameter $50 \mathrm{~cm}$ above the ground, and height growth were determined by the difference in measurements between 17 June and 23 Oct. 1998 and between 23 Oct. 1998 and October 1999. Twelve fully expanded leaves were randomly collected throughout the canopy from terminal growth in June of each year. Leaf area was determined using the Computer Image Analysis System (CID, Inc., Camas, Wash). Leaf mass per area (LMA) was then calculated after leaves where dried and weighed. Samples were then sent to the Ohio State University
Research Extension Analytical Laboratory, Wooster, Ohio for dry combustion analysis of $\mathrm{N}$. Carbon acquisition of the crabapples was assessed by measuring net photosynthesis rate $\left(\mu \mathrm{mol} \cdot \mathrm{m}^{-2} \cdot \mathrm{s}^{-1}\right)$ on fully expanded leaves using a portable photosynthesis system (LI-6200; LI-COR, Inc., Lincoln, Nebr). Measurements were taken on cloudless mornings on 30 and 31 July in 1998 during the drought and on 1 Sept. 1998, following the end of the drought. One single-leafmeasurement was made on each tree on each sampling date.

Evaporation exceeded precipitation by 15.13 $\mathrm{mm}$ the three weeks before the July photosynthesis measurements and the site received no precipitation the week before 30 and 31 July. The 1 Sept. 1998 measurement followed the end of the drought when $17.00 \mathrm{~mm}$ of precipitation fell between 23 and 29 Aug. 1998) (OARDC Climate Records, 1998). Additional photosynthetic measurements were made in 1999 to coincide with similar conditions as were measured in 1998.

On 4 Aug. 1998 and 9 June 1999, 12 leaves were sampled from throughout the canopy of each tree to determine treatment effects on foliar concentration of total phenolic compounds. Leaf age was standardized by sampling only foliage produced during first bud break. Immediately upon removal from the plant, leaves were flash-frozen in liquid nitrogen, placed in a cooler on dry ice, and transported to the laboratory where they were stored at $-80{ }^{\circ} \mathrm{C}$ until they were lyophilized while being held at $4{ }^{\circ} \mathrm{C}$. After freeze-drying, the tissues were weighed and milled to pass through a 40-mesh screen. These samples were subsequently stored frozen until they could be analyzed.

Total foliar phenolic concentrations were quantified using the Folin-Denis assay modified for use with a continuous flow analyzer as documented in detail by Nitao et al. (2001). Before analysis, a 70-mg aliquot was extracted in $50 \%$ methanol for $1.5 \mathrm{~h}$. Purified tannic acid was used as a standard. Concentrations were reported as tannic acid equivalents (TAE) on a percent dry weight basis.

Twelve fully expanded leaves were randomly collected throughout the canopy from terminal growth in June of each year for foliar nitrogen analysis. Samples were sent to the USDAForest Service Laboratory in Rhinelander, Wis., for dry combustion analysis of nitrogen.

Three experiments were conducted to determine effects of nursery fertilizer and irrigation treatments on insect performance. On 7 May 1998, before out planting, experiments were initiated with third instar eastern tent caterpillar (Malacosoma americannum) and third instar gypsy moth (Lymantria dispar), both of which are spring-feeding insects. To determine if effects on insect performance changed throughout the field season, a third experiment was initiated on $25 \mathrm{Aug} .1998$ with first instar whitemarked tussock moth larvae (Orgyia leucostigma), a late season defoliator. Eastern tent caterpillar larvae were collected from native populations; whitemarked tussock moth and gypsy moth larvae were provided by the Canadian Forest Service (Insect Production Unit, Great Lakes Forestry Centre, Sault Ste. Maries, Ont., Canada). The experiments were repeated in 1999 on 20 Apr., 11 May, and 21 Aug. Each of the three experiments was conducted under controlled conditions in the laboratory. Larvae were fed foliage from the experimental trees and their growth determined by measuring their weight immediately before and after the experiment. Each larva was fed five leaves from one tree. Leaves and caterpillars were confined to petri plates ( $15 \mathrm{~cm}$ in diameter, $2.5 \mathrm{~cm}$ high) containing a base of plaster of paris for $48 \mathrm{~h}$ or $10 \mathrm{~d}$. Water added to the plaster base provided a high humidity environment, which maintained the turgor of the leaves. Petri dishes were then randomly positioned in a growth chamber maintained at $25^{\circ} \mathrm{C}$ with an 18 and $6 \mathrm{~h}$ day and night photoperiod.

Data was analyzed using ANOVA to examine main effects of water and fertilization and to determine if there were interactions between the effects. Differences between means were discerned by using LSD means separation at $p=0.05$ (SAS 1999). Pearson's Correlation coefficient $(r)$ was used to examine if there were linear relationships between growth and foliar phenolic analysis and regression was utilized to discern if there is a causal relationship between nitrogen availability and plant diameter growth.

\section{Results and Discussion}

Tree growth. Trunk diameter and height growth in the landscape was related to both irrigation and fertilization treatments from the nursery in 1998 (irrigation: $\mathrm{F}=8.27, p=0.001$; fertilization: $\mathrm{F}=4.03, p<0.026)$. Trees irrigated at $25 \%$ container capacity and fertigated at highest fertilization rate had the greatest diameter growth in the landscape (Table 1). Irrigation schedule in the nursery had no influence on diameter growth in the landscape when plants were grown with $\mathrm{N}$ at $50 \mathrm{mg} \cdot \mathrm{L}^{-1}$ (Table 1). Diameter growth of plants grown with $\mathrm{N}$ at $200 \mathrm{mg} \cdot \mathrm{L}^{-1}$ was greatest when plants received the high irrigation treatment. Trees irrigated at $25 \%$ container capacity and fertigated at either the moderate or high fertilizer rate had the greatest height growth in the landscape (Table 1). Irrigation in the nursery had no influence on height growth in the landscape when plants were grown with $\mathrm{N}$ at $50 \mathrm{mg} \cdot \mathrm{L}^{-1}$. Increasing the nitrogen rate in the nursery had no influence

Table 1. Effects of fertilizer and irrigation scheduling used in the nursery on trunk diameter growth [final trunk diameter (Oct 1998) _ initial trunk diameter (June 1998) and height growth (final height (Oct 1998) _ initial height (June 1998)] of Malus 'Sutyzam' in the landscape following outplanting.

\begin{tabular}{lccccccr}
\hline $\mathrm{N}$ fertilization & \multicolumn{3}{c}{ Low irrigation $(7 \mathrm{kPa})$} & & \multicolumn{3}{c}{ High irrigation $(18 \mathrm{kPa})$} \\
\cline { 2 - 4 } \cline { 7 - 8 } rate $\left(\mathrm{mg} \cdot \mathrm{L}^{-1}\right)$ & 50 & 200 & 350 & & 50 & 200 & 350 \\
\hline Diameter $(\mathrm{Mm})$ & $1.616 \mathrm{ab}^{2}$ & $2.086 \mathrm{bc}$ & $4.082 \mathrm{e}$ & & $1.251 \mathrm{a}$ & $2.637 \mathrm{~d}$ & $2.332 \mathrm{~d}$ \\
Height $(\mathrm{cm})$ & $54.975 \mathrm{bc}$ & $67.888 \mathrm{a}$ & $63.088 \mathrm{ab}$ & & $53.063 \mathrm{bc}$ & $44.375 \mathrm{c}$ & $43.650 \mathrm{c}$ \\
\hline
\end{tabular}

${ }^{\mathrm{z}}$ Means within a row followed by the same letter are similar $(p<0.05 ; \mathrm{n}=48)$. 


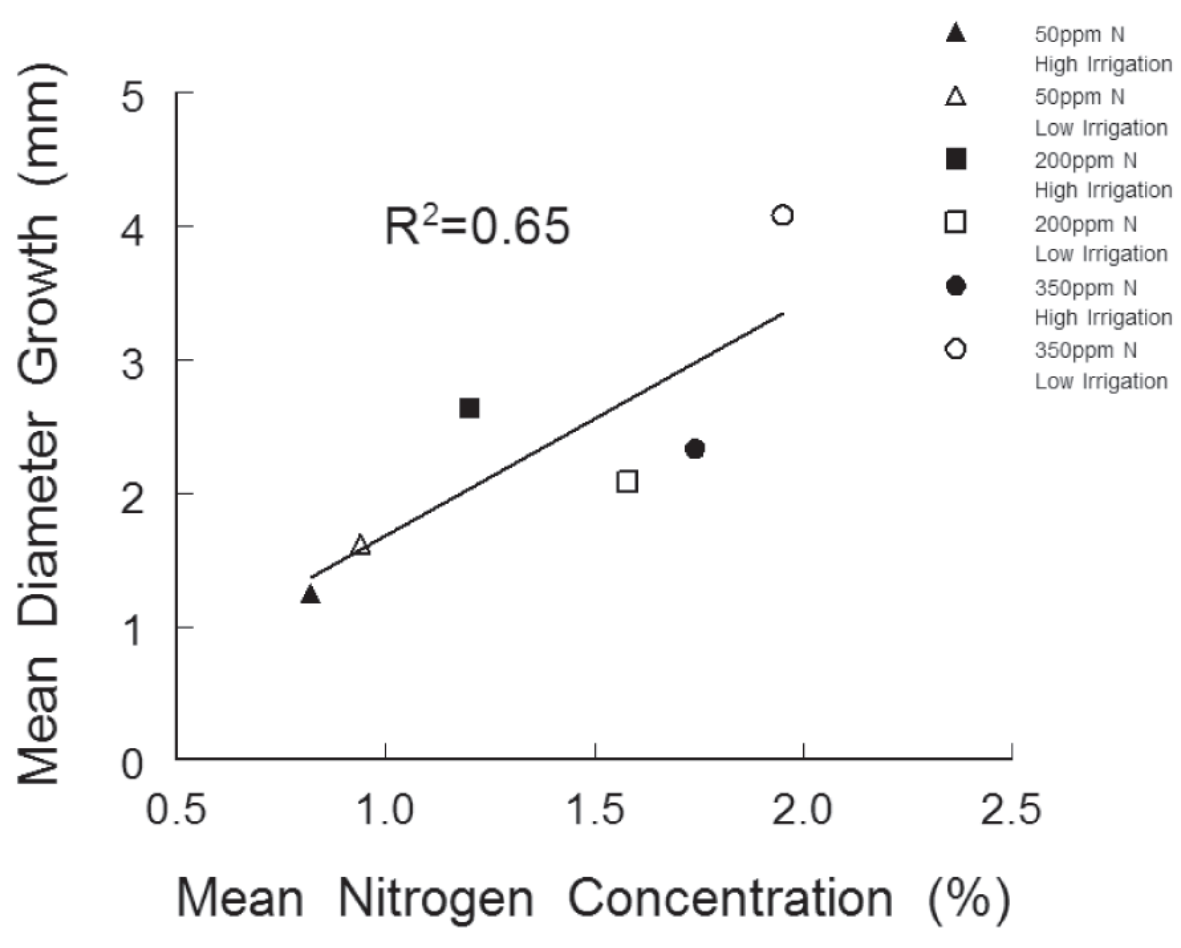

Fig. 1. Relationship between whole plant nitrogen concentration of dormant plants after one season of nursery treatments and subsequent growth for 1998 of Malus 'Sutyzam' in the landscape following outplanting.

on height growth of plants receiving the high irrigation treatment; however increasing the nitrogen rate in the nursery did increase height growth of plants that received the low irrigation treatment. LMA was not influenced by fertilizer or irrigation treatments in the nursery.

Stem growth, measured as dry weight, was greatest for the low fertilizer treatment in the nursery (Rose, unpublished data). The difference in which treatment had the greatest trunk growth between the nursery and landscape can be explained if nitrogen accumulated by the tree in the nursery was stored and then used to support growth the following year. Indeed, plants with higher N concentrations in December 1997 grew more in the landscape in 1998 (Fig. 1). The differences in growth in 1998 did not continue through 1999, further supporting this hypothesis.

Photosynthesis and stomatal conductance. As plants are stressed by moderate to severe drought, photosynthesis becomes limited by closure of stomata. Stomatal conductance is a measure of the rate at which water vapor moves from the leaf through the stomata to the atmosphere via transpiration. As stomata close and transpiration decreases, stomatal conductance declines. Closure of stomata conserves water by decreasing transpiration, but at the same time decreases uptake of $\mathrm{CO}_{2}$ from the atmosphere.
Plantresponses to drought are genotype specific. Drought tolerant plants maintain higher rates of photosynthesis and stomatal conductance during drought than do plants that are less tolerant of drought stress (Kubiske and Abrams 1993; Schulze 1986). Thus, since the trees were clones any differences in drought tolerance can be related to the nursery treatments before transplant.

The fertilizer regime used in the nursery had clear effects on drought stress tolerance following outplanting in 1998 (Table 2) while irrigation in the nursery had no effect on drought tolerance after planting. Trees receiving the lowest rate of fertilizer in the nursery maintained significantly higher photosynthesis and stomatal conductance rates compared to those of trees receiving the high fertilizer treatments rates during the drought period (Table 2). This indicates that plants grown at low fertility in the nursery were more tolerant of drought conditions in the landscape than plants grown at a higher fertility in the nursery. On 1 Sept. 1998, after drought conditions hadabated, the photosynthesis and stomatal conductance rates of all trees increased dramatically and treatment effects on photosynthesis rates were absent. Stomatal conductance of trees grown with the highest fertilizer rate in the nursery, however was still significantly lower than stomatal conductance of trees in other fertility treatments. The effect of fertilization rate in the nursery on photosynthesis and stomatal conductance that were observed in 1998 did not occur in 1999, suggesting that the treatments were no longer affecting tree performance. Photosynthesis rates for 1999 ranged between 0.76 and $21.01 \mu \mathrm{mol} \cdot \mathrm{m}^{-2} \cdot \mathrm{s}^{-1}$ and were not influenced by fertilization or irrigation treatments $(\mathrm{F}=0.66, p=0.78)$.

High rates of $\mathrm{N}$-fertilization may decrease drought stress tolerance for a number of reasons. Increased nitrogen availability generally stimulates shoot growth to a greater degree than root growth, thus decreasing the root:shoot ratio of the tree (Linder and Rook, 1984). In this way, fertilization can simultaneously increase tree water demands while decreasing the tree's ability to acquire water during drought. Trees receiving the low fertilizer treatment in this experiment had a higher root:shoot ratio when they left the nursery (Rose et al. 1999), which could have been responsible for their increased tolerance of drought stress.

Foliar phenolic concentration. Trees in the landscape with larger trunk diameters had lower concentrations of phenolic compounds in the foliage (Fig. 2) regardless of irrigation treatment. This negative relationship is consistent with a trade-off between growth and carbohydrate allocation to secondary defensive chemistry (Herms and Mattson 1992). The reduction in phenolics suggests that the rapidly growing trees from the high fertility treatments were allocating less photosynthates to secondary processes compared to trees grown at lower fertility in the nursery.

The high rates of fertilizer may have decreased drought stress resistance through effects on the chemical composition of leaves. A well-documented effect of high fertilization rates is a decrease in foliar concentration of tannins and other secondary metabolites that provide trees with stress tolerance and insect resistance (Herms and Mattson, 1992, Keinanen et al., 1999, Ruohomaki et al., 1996). Tannins impregnate the outer wall of epidermal cells, making them more impervious to water, and thus contribute to water conservation under stress (Bussotti et al., 1998).

Insect performance. Numerous studies provide strong evidence that fertilization almost always decreases resistance of trees to defoliating insects (Herms, 2002), most likely because fertilization generally increases the nutritional value of plants and decreases concentrations of the trees defensive chemicals (Herms and Mattson, 1997). Our results with crabapples are consistent with this pattern. As the fertilizer rate used in the nursery increased, so did the insect weight growth (Fig. 3). Irrigation effects were imperceptible. This pattern was

Table 2. Effect of fertilizer regime used in the nursery on net rate of photosynthesis and stomatal conductance of Malus 'Sutyzam' in the landscape following outplanting (mean \pm standard error).

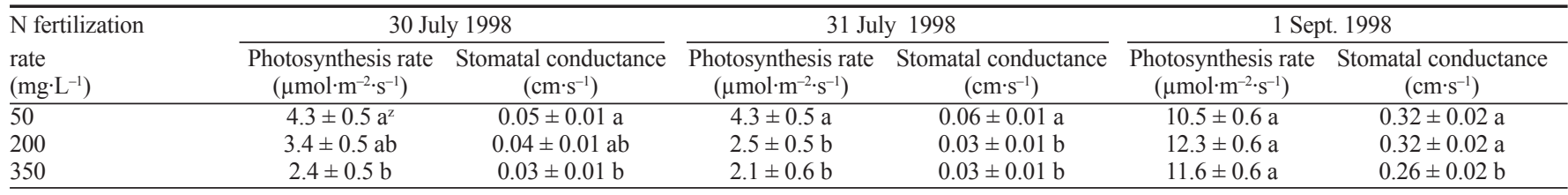

${ }^{\mathrm{z}}$ Means within a column followed by the same letter are similar $(p<0.05 ; \mathrm{n}=48)$. 


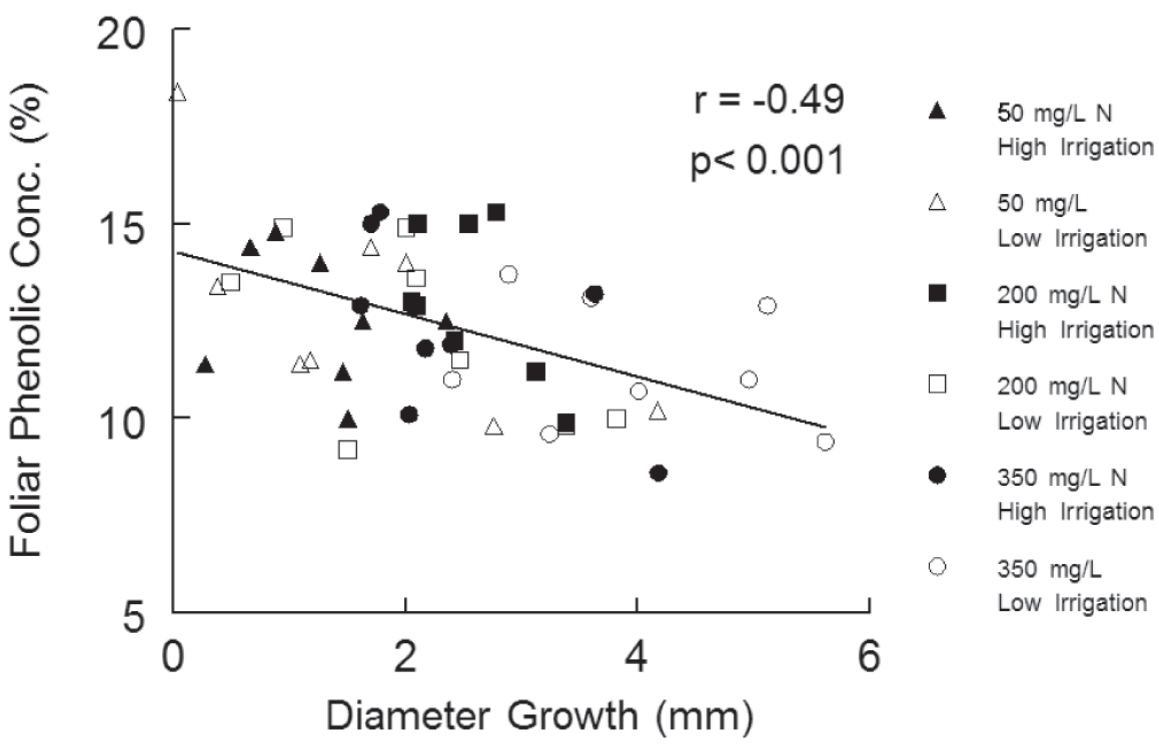

Fig. 2. Relationship between trunk diameter growth (final diameter - initial diameter) and foliar phenolic concentrations measured in August foliage samples.

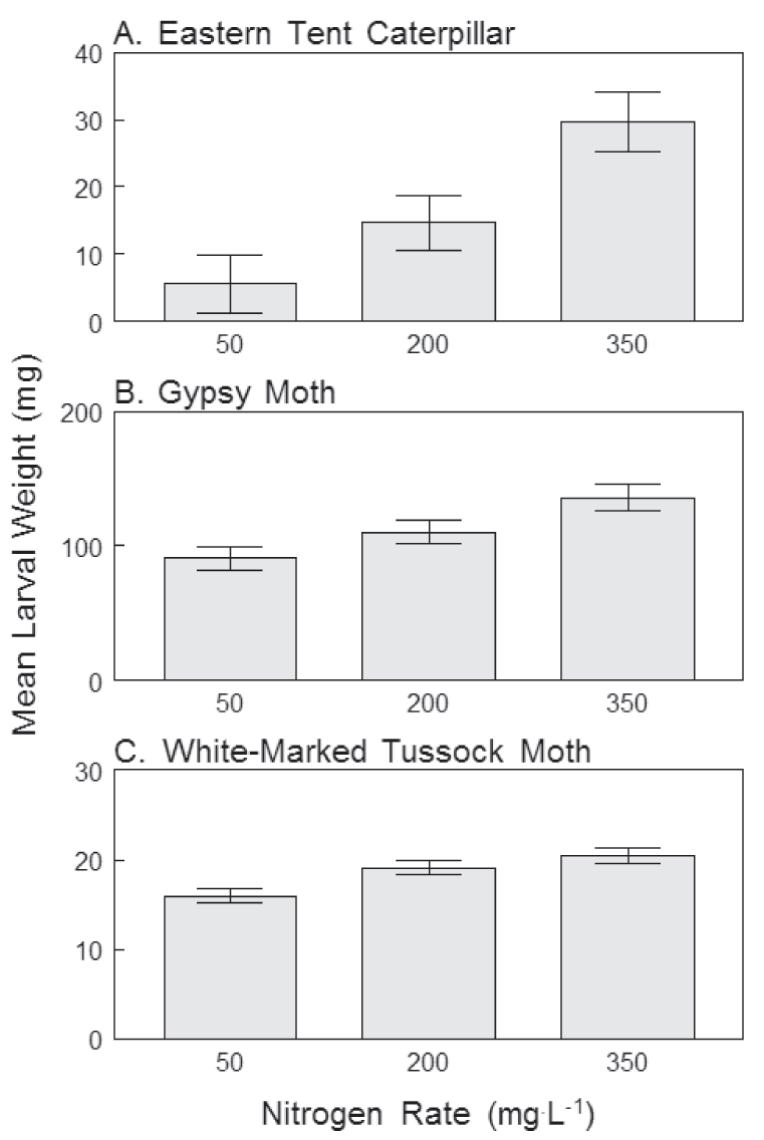

other parameters we measured, differences in insect performance were not detectable in 1999. Thus the impact of nursery treatments on the insect performance of larvae feeding on the crabapples appears also to be related to the environmental resources from the previous season.

\section{Conclusions}

The fertilization and irrigation regime used during the growing season in the nursery had major effects on the growth (height and trunk diameter) after outplanting. The impacts of irrigation scheduling, however, had little impact on the stress resistance traits of the trees in our study.

Fertilization was the primary influence on stress tolerance, and insect performance on 'Sutyzam' crabapple in a low-maintenance landscape the following season.

Increased $\mathrm{N}$ concentrations of trees in the nursery can increase tree growth in the landscape, however, trees subjected to higher fertilizer rates in the nursery showed decreased drought stress tolerance and supported

Fig. 3. Effect of fertilization regime in the nursery on the larval weight growth (final weight-initial weight) of eastern tent caterpillar (A), gypsy moth (B), and white-marked tussock moth (C) larvae feeding on Malus 'Sutyzam' spring foliage (mean \pm standard error; $\mathrm{n}=48$ ).

true for both early season (gypsy moth and eastern tent caterpillar) and late season (whitemarked tussock) species, however the increase in weight growth for white-marked tussock moths between the moderate and high fertility treatments was not significant. As with the

\section{Literature Cited}

Bussotti, F., E. Gravano, P. Grossoni, and C. Tani. 1998. Occurrence of tannins in leaves of beech trees (Fagus sylvatica) along an ecological gradient, detected by histochemical and ultrastructural analyses. New Phytol. 138:469-479.

Cabrera, R.I. 2003. Nitrogen balance for two containergrown woody ornamental plants. Scientia Hort. 97:297-308.

Franco, J.A., V. Cros, S. Banon, A. Gonzalez, and J.M. Abrisqueta. 2002. Effects of nursery irrigation on postplanting root dynamics of Lotus creticus in semiarid field conditions. HortScience 37:525-528.

Franco, J.A., V. Cros, S. Banon, J.J. Martinez-Sanchez. 2002. Nursery irrigation regimes and establishment irrigation affect the postplanting growth of Limonium cossonianum in semiarid conditions. Israel J. Plant Sci. 50:25-32.

Hamilton, D.R., M.e.C. Graca, and S.D. Verkade. 1981. Critical effects of fertility on root and shoot growth of selected landscape plants. J. Arboric. 7:281-290.

Herms, D.A. 2002. Effects of fertilization on insect resistance of woody ornamental plants: Reassessing an entrenched paradigm. Environ. Entomol. 31:923-933.

Herms, D.A. 1999. Physiological and abiotic determinants of competitive ability and herbivore resistance. Phyton 39:53-64.

Herms, D.A. and W.J. Mattson. 1992. The dilemma of plants: to grow or defend. Qrtly. Rev. Biol. 67(3):283-335.

Herms, D.A. and W.J. Mattson. 1997. Trees, stress, and pests, p. 13-26. In: J.E. Lloyd (ed.). Plant health care for woody ornamentals. Intl. Soc. Arboricult., Champaign, Ill.

Keinanen, M., R. Julkunen-Tutto, P. Mutikainen, M. Walls, J. Ovaska, and E. Vapaavuori. 1999. Tradeoffs in phenolic metabolism of silver birch: Effects of fertilization, defoliation, and genotype. Ecology 80:1970-1986.

Khan, S.R., R. Rose, D.L. Haase, and T.E. Sabin. 1996. Soil water stress: Its effects on phenology, physiology, and morphology of containerized Douglas-fir seedlings. New For. 12:19-39.

Kubiske, M.E. and M.D. Abrams. 1993. Stomatal and nonstomatal limitations of photosynthesis in 19 temperate tree species on contrasting sites during wet and dry years. Plant Cell Environ. 16:1123-1129.

Linder, S. and D.A. Rook. 1984. Effects of mineral nutrition on carbon dioxide exchange and partitioning of carbon in trees. In: G.D. Bowen and E.K.S. Nambiar (eds.). Nutrition of plantation trees. Academic Press, London.

McAlister, J.A. and V.R. Timmer. 1998. Nutrient enrichment of white spruce seedlings during nursery culture and initial plantation establishment. Tree Physiol. 18:195-202.

Nitao, J.K., B.A. Birr, M.G. Nair, D.A. Herms, and W.J. Mattson. 2001. Rapid quantification of proanthocyanidins (condensed tannins) with a continuous flow analyzer. J. Agr. Food Chem. 49:2207-2214.

Rieske, L.K., C.C. Rhoades, and S.P. Miller. 2003. Foliar chemistry and gypsy moth, Lymantria dispar (L.), hervibory on pure american chestnut, Castanea dentate (Fam: Fagaceae), and a disease-resistant hybrid. Environ. Entomol. 32:359-365.

Rose, M. 1994. Monitoring rose oscillatory transpiration by integrating a greenhouse climate control computer and physiological sensors. PhD diss. Pa. State University, Univ. Park.

Rose, M.A., M. Rose, and H. Wang. 1998. Fertilizer concentration and moisture tension affect growth and foliar N, P, and K of two woody ornamentals. HortScience 34:246-250.

Ruohomaki, K., F.S. Chapin III, E.Haukioja, S.Neuvonen, and J. Suomela. 1996. Delayed inducible resistance in mountain birch to fertilization and shade. Ecology 77:2302-2311.

SAS Institute, 1999. SAS/STAT users guide. vol. 2. (8th ed.) SAS Inst., Cary N.C.

Schulze, E.D. 1986. Carbon dioxide and water vapor in response to drought in the atmosphere and in the soil. Annu. Rev. Plant Physiol. 37:247-274.

Struve, D.K. and M.A. Rose. 1998. Early-season fertilization reduces fertilizer use without reducing plant growth. J. Environ. Hort. 16:47-51. 